\title{
THE SOCIOLOGY OF ENTERPRISE, ACCOUNTING AND BUDGET RULES: IMPLICATIONS FOR ORGANIZATIONAL THEORY
}

\author{
MAYER N. ZALD* \\ University of Micbigan
}

\begin{abstract}
The sociology of organizations has ignored the evolution of and variation in enterprise rules, budget systems and accounting rules. This paper takes a broad approach to accounting rules, arguing that they are related to large variations in enterprise forms and in industry problems. The rule making and enforcement apparatus of modern society is described. Both external and internal aspects of accounting rules and budget systems are explored.
\end{abstract}

Every manager spends a good deal of his time worrying about budget allocations and the application of specific rules. The overall budget system and the specific allocation policies are for the individual manager an accounting-budgeting regime. For many purposes, and at most times, they are treated as from God - timeless and unchangeable, possibly arbitrary, but determinative. Even if the manager tries to evade them or manipulate them, he does so with a sense of testing the fates. Moreover, sovereigns, supreme authorities, spend much time creating budgets, reviewing accounting information, creating and thinking about accounting systems, and processing information derived from these systems.

But it is striking how little attention sociologists of organizations have given to the analysis of accounting and budgeting systems, how little attention they have given to the rules governing ownership - the transfer of property rights from one group or individual to another.
For instance, if one examines the index of leading books written by sociologists of organizations one finds little mention of money, finances, accounting, or budget. None of these terms appear in W. Richard Scott's, Organizations: Rational, Natural, and Open Systems (1981), and this is an extraordinarily fine book. Or again, if one examines the index of Charles Perrow's important, Complex Organizations: A Critical Essay (1979), there is one reference to budget, none to accounting, and none to financing. There is a single reference to fundraising. ${ }^{1}$ Richard Hall's textbook, Organization, Structure and Process (1981) has no references to accounting, budgeting, or finance; one does find two references to economic factors. There are several references to resources. The same lacuna is found in James D. Thompson's classic book, Organizations in Action (1967). There is a brief discussion of planning and budgeting under the discussion of coordination by planning, but that is more a general discussion of scheduling than it

\footnotetext{
- Delivered at Symposium on the Role of Accounting in Organizations and Society, University of Wisconsin-Madison, 12-14 July, 1984.

'It is ironic that Perrow doesn't discuss budget processes more, since one of the finest chapters in his doctoral dissertation (1960) deals with a chief executive's manipulation of the budget and capital expenditure classification.
} 
is of budgeting. There may be in these books some discussion of resource acquisition, but very little discussion of the rules governing resource acquisition and allocation. Even among theorists who make power dependence and resource balance issues central to the analysis, such as Jeffrey Pfeffer, there is little discussion of specific accounting systems, budget rules, allocation schemas, as these operate to shape the operation of organizations, their growth and transformation. In the index of Pfeffer's Organizations and Organization Theory (1982), there are three pages cited on budget allocation, no discussion of accounting rules, one reference to capital allocation, no reference to finance, and no reference to money.

The reasons for this neglect of accounting and budget rules as shapers of organizational behavior and as major sources of variation between organizations are complex. Note that political scientists (Wildavsky, 1979) and economists (Niskanen, 1971), dealing with public organizations and public expenditures, have developed a substantial literature dealing with budget systems. But for the private sector, until recently, accounting and budget systems have been treated as outside the domain of political scene and sociology.

Economists have assumed the rationality or improvability of accounting rules. Accounting rules are seen as either economizing devices or as political-traditional imperfections and barriers to economizing. Economists treat technology as a hard constraint on production functions (e.g. changeable, but outside the economist's domain ), and therefore they analyze the implications of technology for cost. But they assume that accounting rules are improveable if we would only be rational in our approach to organizations. They do not, by and large, treat management technology as real. Accounting rules may be an imperfection but not a hard constraint.

Sociologists have given much attention to technology-task constraints on organizations. They also have extensively analyzed power and authority. In many organizations a major component of the system of rule is expressed through budgets and accounting rules by making allocations. These have been largely ignored by sociologists. Why sociologists have ignored the issue is a matter for the sociology of knowledge. Sociologists of organizations found accounting to be dry. Accounting seemed fixed. In a sense, accounting rules have been treated as givens, as part of a technical-cultural process which need not be analyzed.

I believe that we are about to witness a large scale change in the utility of analysis of accounting and budget rules and enterprise rules for the analysis of organizations. I feel a bit like Rip Van Winkle. I went to sleep ten to fourteen years ago, believing that an important topic was overlooked (Zald, 1970a, b). During the last decade I have largely worked in other areas, only occasionally doing work on organizations. Now, as I return to the study of complex organizations, I find an active research community addressing issues of budget and accounting systems. New journals, such as Accounting, Organizations and Society, directly address problems of the relationship of organizations and accounting. Economists working on the theory of property rights and agency, are very much aware of the role of incentive systems, incentive rules and financing arrangements for affecting organizational behavior and outcomes. Authors such as Feldman \& March (1981, concerned with signalling of facts and the processing of information, lead us to examine the accounting systems and budget systems which are major processors of information for organizations.

I find it somewhat strange, however, that, although there has been increasing interest in these topics by scholars either interested in organization theory, or the effects of incentive systems, these interests have not penetrated more general theoretical treatises. Until they do, general discussion of control and authority will remain abstract and detached. In this paper I wish to outline a research program and a set of research topics that would eventually allow us to show how organizations are deeply shaped by enterprise rules, by various accounting and investment rules and systems. I see the venture as potentially useful for accounting researchers, 
but even more important for a deep, historically based, culturally informed analysis of organizations.

Our topic is broader than just a focus on accounting rules: I take it that accounting rules and accounting practice are methods for measuring and assigning costs and incomes to various categories for use in information systems. In a narrow sense, the sociology of accounting rules would not deal with budgets, would not deal with financial investment measurement systems, would not deal with the larger processes and rules governing property rights in organizations and criteria for changing property rights. Accounting and budget systems are set up within a set of sovereign relations, yet sovereign relations are not given, and the choice of enterpriseproperty rules affects accounting rules and relations. Changes in the law of corporations affects accounting rules and practice. I believe that nesting the narrower analysis of accounting rules in the larger budget-property rights system, both internal and external to organizations, will lead to a fuller understanding of the regulated and rule-based nature of organizations.

The system of enterprise rules, accounting regulations and budget and accounting practices that shaped the behavior of the fourteenth century merchant of Florence was much different from those surrounding the railroad magnate of the late nineteenth century. And those, in turn, were much different from those surrounding the late twentieth century real estate developer. Only as we understand more of those differences and learn to think about them will we grasp the essential transformations and differences among organizations.

\section{WHAT KIND OF ORGANIZATIONAL THEORY?}

What type of organizational theory will best end up accommodating and being invigorated by close attention to rule systems and budget allocation systems? First, the theory or framework has to see the evolution of organizations and related accounting systems in historical context. Of course, the trends of modern life and of mod- ern society are such as to spread accounting budget systems across nations. Thus, Leontief's input-output matrix accounting for national economies may be as useful in Gambia and Grenada as in Great Britain. Nevertheless, over time and in different industries at different times, and in different types of socio-economic systems, the nature of accounting rules, the type of system selected, vary substantially. The rule systems that we are talking about are part of cultural systems for societies as a whole. (National boundaries are permeable boundaries.) Any rule or rule system develops in one organization, or to meet specific emerging problems and then is implemented in many other organizations or situations. The usual pattern is for a process of innovation, proposal, dissemination through professional groups and professional socialization and transmission to individual organizations and institutions. This occurs both through the good practice manuals of professional groups, textbooks, the practices of auditing firms and the requirements of key external groups such as the Securities Exchange Commission, the Internal Revenue Service and the civil and criminal courts. So, in the first instance, the theory or the organizational framework has to be one that is open to historical context and experiences the process of adoption and implementation.

Second, as implied above, the framework has to be open to, and sensitive to, industry and organizational differences. The rules that get applied, the accounting-financial regimes, are sharply structured by industry differences, by how accountants, executives and regulatory agencies have come to grips with the problems of control and allocation in specific industries. Insurance accounting is different from public utility accounting, which, in turn, is different from hospital accounting. They differ in their reserve requirements, in the relation of accounting information to managerial decisions, and so on. Moreover, not-for-profit government agencies, partnerships, and corporations have fundamentally different reporting requirements and accounting systems. And of course, the accounting allocating systems that exist in socialist societies will differ on fundamental dimensions 
from those in capitalistic systems.

Third, the organizational theory should understand the play of adoption and reaction to rules in specific organizations. For example, all research universities in the United States must have procedures for estimating indirect costs on research grants and allocating revenues from indirect cost returns. While the former may be standardized to meet government auditing requirements, the latter varies widely, so that indirect costs in some universities flow through directly to the research investigator or the research unit, and in other universities indirect cost returns are loosely coupled to the decision process as to how much space, equipment and facilities to give the research generating units.

What kind of theories or theoretical framework will be most useful? It seems to me that we first can say that some theories, or theoretical frameworks, while very valuable for some classes of problems, will not turn out to be very useful to the study of organizational rule systems, accounting rules and budget allocations. In particular, I do not believe that population-ecology models (Hannan \& Freeman, 1977), or abstract organization-environment models and approaches are nuanced enough to come to grips with the textured nature of accounting rules and budget systems. The more abstract models seem to assume much of the rule system as an intervening black box in examining the more macro processes. Their conceptualization of environ'ment harks back to general systems theory or biological analogy, denuding society of political economy systems, of goals, values, human agency, power and conflict. On the other hand, I believe that approaches drawing upon the process of institutional, cultural understanding in generating rule systems and acceptance of budget accounting procedures will be quite useful (Meyer \& Rowan, 1977). For John Meyer and associates institutional processes surround organizations. They are not merely rational-technical production systems. Instead, they are imbedded in legitimation processes and expectations. Accounting systems are part of institutionalized expectations. I also believe that micro analyses dealing with symbol construction, detailed, al- most anthropological, historical analysis of rules will be very interesting and useful.

For myself, however. I believe that a fruitful way to go is found in a marriage between the new Marxist based theory of organizations as reflected in the works of Stuart Clegg (1981) and others and the older institutional analysis reflected in the works of Phil Selznick (1948, 1949), Alvin Gouldner (1954), Burton Clark (1983), and my own political economy analysis (Zald, 1970a,b). Since the organizational analysis $a$ la Selznick and early Gouldner is well known, let me discuss for a moment the advantages of utilizing a new-Marxist approach that is wedded to this kind of organizational analysis (Goldman, 1984).

The large claim that I am making is that organizational theory must become more historically grounded, must be attuned to the larger system in which organizations exist. To say that organizational theory must be historically grounded means more than that it must take account of time and historical change. We have had a discipline of administrative history and of business history that has been of little value to the more generalizing aims of organizational theory. Except for the seminal works of Alfred Chandler $(1962,1977)$, organizational history has not informed more sociological concerns. The kind of organizational history, or historical perspective, that will be of value is one that has a motor of systemic change behind it. Whether it is a theory of societal rationalization in a Weberian sense (McNeil, 1978), a theory of political-state transformation (Therorn, 1978; Skowronek, 1982), or a theory of the major institutional trends of economy and society, the larger matrix must be understood as undergoing transformation in some system property sense, rather than merely historical change. Chandier has a sense of administrative response to size and complexity but misses, or pays little attention to, either the transformation of labor relationships or the larger political economy of capitalism. Much of what accounting does is fuel reports and relations to government and a changing banking-investment matrix (Burk, 1982; Mintz \& Schwartz, 1985). 
In recent years, a school of Marxist, or Marxist-oriented, writers have begun to examine the transformation of organizations. Edwards (1979), Burawoy (1979), Braverman (1974), Clawson (1980), and Clegg (1981) are representative writers. These writers are largely concerned with the transformation of management-labor relationships. The shop floor is a situs for class conflict and control over the accumulation-appropriation cycle. For Clawson, for instance, bureaucratization is a tool of managerial control over labor and the contracting. out system. What all of these authors share is a sense that organizational change reflects larger changes in bourgeoisie, managerial and working class relations. But such a perspective leaves out much and would by itself have little to do with the topic of this paper. In a sense, these authors look at management-labor relationships and their change to the exclusion of the other transformations of firms and organizations in a capitalist society. There is little about conflict between organizations or conflict between capitalists and managers, or conflict between elite class fragments, or conflict between large corporations and small organizations, or conflict between stockholders and the norms, or theics, of public regardingness and the norms of buccaneer capitalism. There is little sense here that government's role as an actor has had a major impact on the budget-accounting systems of organizations, not only through things such as the Securities Exchange Commission and related legislation, but through a variety of taxes and reporting requirements. Intriguingly, by being so attuned to the shop floor, much of this literature ignores the large political transformations that have reshaped both the shop floor and politics in Western societies (but see Burawoy, 1983).

Stewart Clegg ( 1981 ), however, begins to lay out a framework which can be exploited for this larger agenda. Clegg essentially sees organizations as social locations where a number of groups and classes interact and conflict. Moreover, the conflicts and differences of interests that are expressed in any single organization are carried along over time and may represent class fragment interactions. Segments of capital may conflict over control of specific organizations. Elite networks create conflict for control and fight to control a given corporation or industry. Owners and large capitalists may require accounting systems and incentive systems, as they become removed from everyday operations, from the needs of the owner-manager. There may develop conflicts between line and staff managers that reflect themselves in professional sub-groups and professional standards in the imposition of power relations. Managers and workers may have different relationships. Petit bourgeoisie, small capitalists, may have a different set of needs and relationships with large corporation managers than petit bourgeoisie owners with each other. Each of these conflicts, or potential conflicts, may involve both external professional groups and state action. The demands for state action, or for professional standards, take particular organizational needs and conflicts out into a professional-public arena where laws, administrative regulations and institutions are established both to regulate the behavior of organizations to establish norms for the given sector, and to set up new institutional arrangements. In this process the interests of individual groups get transformed into a politicalnormative bargain that establishes regulations which may benefit some and hurt others. Over time, the new regulations, or new standards, become the baseline for further changes in accounting, or in the stock market, or in tax policy as the new regulations become opportunities for groups to exploit at a more micro level until another cycle of change takes place. The ongoing "game" as described by Crozier \& Friedberg (1980) is nested in this larger systemic change.

Clegg's contribution is very important because it permits a historically oriented state-organization interaction. But there are limits to the new Marxist perspective. First, the new Marxists tend to underplay industry differences (but see Zimbalist, 1980). In the quest for historical generalization, they tend to underplay the extent to which the capitalist system varies in important ways by industry structure.

Second, as noted above, the new Marxists have been much more concerned with labor- 
management relationships, to the detriment of the analysis of other aspects of organizational development. There is little attention to the competitive nature of industries and to how change in the technological processes and in production, transforms organizations and creates demands for organizational structures of coordination and control. Managerial structure, so ably analyzed by Chandler (1962, 1977) is ignored. There is little attention to the institutionalized normative system surrounding profit and practice in industries. The financial rule structure surrounding extractive industries is very different from the financial rule structure surrounding the banking industry or the insurance industry.

Third, different nations, equally called capitalist, will webb the flow of capital and the intersection of centralized decision making with organizations in a very different way. To this point, the Marxist sociologists have been unready to address these issues (though political scientists have). Finally, this work addresses labor-management relations only in profit making firms. They have not addressed the issue of state firms, of non-profit firms, and so on. Yet it ought to be clear that a major transformation of the modern world is the growth of either publicly owned organizations or organizations dependent upon the public fisc. We live in a world in which most of the airline companies of the world, in which most of the banking systems, in which many automobile manufucturers, in which many airplane manufacturers, in which almost all utilities are either publicly owned or publicly regulated. An analysis of the variety of budget-accounting systems and larger rule systems must certainly be attuned to this master trend.

Although the new Marxists give us a major tool for thinking about regulations as a part of class conflict and state action, they have less to say about organizational dynamics per se, partly because their object of analysis is not really organizational change or even organizational control. What kinds of tools do we have to pay more attention to organizations per se? I want to suggest that organizational analysis of the
Selznickian type (1949), or my own political economy approach ( $1970 \mathrm{a}, \mathrm{b})$, combined with a strong emphasis upon differences in the financial-technological-regulatory-matrix of specific industries will take us far along the way.

Selznickian analysis is holistic. It treats the interplay of organizations in environments. It examines the goals, conflicts, and commitments of the powerful and the powerless as they interact to produce products and obtain resources and legitimacy from the environment. My own political economy approach uses a strong analogy to societal political economy. It examines the interaction of the internal political structure and economy (system for producing goods and services) with the external polity and economy in which it finds itself.

In the remainder of the paper I wish to take up specific topics in which a historical-organizational approach will use the rule setting process, the accounting budget process, as aspects of organizational analysis. First I will discuss enterprise rules, the transformation of rules or property rights, property ownership, and financial investment that can transform the operation of organizations. These property and enterprise rules set constraints on accounting and budget allocation systems. Secondly, I discuss the external process of rule making and rule setting and its impact upon accounting procedures. Third, I will touch upon enterprise forms and industry differences in accounting and budgeting regimes. Fourth, I will discuss the valuational-accounting process and budget systems within organizations.

\section{OWNERSHIP RIGHTS, COMBINATION RULES, AND ENTERPRISE TRANSFORMATION}

The making of modern capitalism is directly related to the growth of the corporation as an enterprise form. While other forms continue sole proprietorships, partnerships, not-for-profit enterprise, government ownership, cooperatives - all capitalist societies have developed a substantial corporate sector. Moreover, public regulation of the terms of ownership of non- 
governmental forms has increased, especially in corporate regulation. There is a substantial literature on the growth of the corporate form. [See the classic work by John Davis (1961); for its economic-control advantage from a property rights perspective see the work of Fama \& Jensen (1983).] One master trend of capitalism was the development of the unrestricted corporation. The growth of the corporate form was facilitated by and, in turn, led to the transformation of financial markets. A second master trend, at least in the United States, deals with the regulation of corporate ownership - from the establishment of regulated stock markets to anti-trust laws.

If we were to carry out Clegg's agenda we would show how, as the corporate capitalist system developed, growth and change led to demands for political change, creating public regulation. That history would show a kind of phase movement of either economic-political crisis or scandal, social movement and political agenda setting, legislative enactment, and then a transformed rule system in which players (large controllers of wealth) interact in the game of accumulation and control.

That is the large macro picture. But, for those interested in the game, there is a micro picture of change that also deserves attention. There is a set of rules which have changed over time, regulating the terms of takeover bids, of declaring intention to buy, of the conditions under which ownership of stock translates into rights to nominate board members, and so on. There are rules governing who bears the cost of proxy fights, rules governing board members' fiduciary responsibility in general and in the face of take. over bids. Each change in rule benefits different parties - intrenched management, large shareholders, small shareholders, outside investors, foreign versus local investors, and so on. These micro rules, combined with economic trends for industries, accounting rules which lead to the over-or-under-valuation of properties, tax liabilities, and the larger anti-trust laws, shape the ongoing expression of merger-takeover activity.

To sharpen the analysis let me suggest the fol- lowing general propositions that bear on organizational control and merger processes:

I. Within the political economy of capitalism, the transformation of enterprise rules affects the potential balance of power and control between (1) internal top management and outside investors with access to large pools of monies; (2) the ability of families to continue to control enterprises they develop; (3) the extent to which the short and long term interests of stockholders are protected in the contests for control of enterprises.

II. Anti-trust rules effect the structure of organizations and industries in that they shape investment opportunities across and between industries. Choices of conglomeration, within industry oligopolization and vertical integration, all respond to enterprise rules.

Since managerial strategies, tasks and organizational structure are shaped by the number of product lines, inter-relations of material transformation tasks internalized in the firm and number of related and unrelated markets that the firm faces, enterprise rules indirectly affect managerial strategy. Finally, the structure of power in capitalist nations is shaped by these enterprise rules.

Although the focus has been on enterprise rules in the for-profit sector, a parallel analysis could be made for the governmental sector and for other enterprise forms. Note, for instance, how the American polity leaves formal authority to local and state governments in contrast to either the U.K or France. "Property rights" of local officials are deeply vested in the United States, where they are negligible in France. The hot debate in the U.K. in the summer of 1984 was whether Margaret Thatcher had violated the British Constitution as she moved to denude local governments of authority.

\section{RULE MAKING, SURVEILLANCE, AND ENFORCEMENT}

Enterprise rules and accounting rules are different in that the former deal with property 
rights, the ownership and rights of disposal and allocation of goods and services, facilities and equipment, while the latter deal with the valua. tion and recording of property, goods and services. They are similar, however, in that for many purposes the rules are set external to the enterprise. In an earlier set of papers ( $Z$ ald, 1978; Zald \& Hair, 1972; Wiley \& Zald, 1968) I attempted to examine the processes by which modern society creates a social control matrix for industries, a class of organization producing relatively similar goods and services. The argument was that, to understand the social control of organizations, you had to take into account (a) that a major source of control was market forces, and markets. The term "markets" applies to competing organizations, that is industries, and (b) that society developed rules and regulations that were industry and technologically specific. There are control agents and procedures for the education industry, for medical accreditation; there are control agents and procedures for the regulated utilities and for the construction industry, and for boiler inspection and insurance. So, to understand social control of industries, products and processes, you had to examine the organized processes of control.

Once you begin to dig into non-market mechanisms of control, the visible, rather than the invisible hand, you also need to make a distinction between rule making, infraction surveillance, and enforcement.

Rule forming, surveillance and enforcement may be a function of one agency. Or they may be more or less separate tasks. In the accounting area, relevant rules are established by professional standard setting boards such as the Financial Accounting Standards Board. Their use, or the application of the rules, is surveyed by auditors, and the rules are enforced by auditors, investors, the courts, the Securities Exchange Commission, and Internal Revenue Service. There is an inter-linked social control process in which information of malfeasance, or even the hint of malfeasance, triggers reactions. More than many social control areas, auditors and accountants are subjected to formal probity norms, to standards of disinterestedness, that are remarkable. Contrast the norms for outside legal counsels and for auditors. Although auditors are hired by the company that they audit, their continuing credibility depends upon their independence. However, note that auditors have a leeway in interpreting and applying rules and are dependent on clients for their income. As accounting firms have added management consulting services, they have become increasingly intertwined with their clients.

A major characteristic of the social control system surrounding publicly held corporations in the United States is that there is a dense network of intensely interested onlookers - the business media, lenders, investors, and business analysts. Many of these onlookers are potential sanctioners. Surveillance and reports of malfeasance translate quickly into the sanctions of many onlookers.

There is a growing body of literature dealing with the sociology and politics of standard setting in accounting (Watts \& Zimmerman, 1978; Holthausen \& Leftwich, 1983). And there is also a growing body of literature on the impact of accounting information on stockmarket performance. Moreover, as banking crises have accelerated in recent times, the efficiency of these regulatory mechanisms has been questioned. What is lacking is a sense of the inter-penetration of control mechanisms. Although articles and books about specific regulatory mechanisms may treat the history of that specific rule or organization, they too often insulate the history from larger systemic trends. James Burk's recent dissertation (1982) on the transformation of the stock market, the institutionalization of the stock market, the growth of fiduciary investment in pension funds and insurance companies, and the development of prudential norms, is a good example of an institutional analysis that helps us understand some of the transforming enterprise rules in institutions as control agents. The Burk dissertation, which does have good historical sense, is a welcome addition to the literature. But note that in focusing upon a specific institution, the stockmarket and investment norms of insurance companies and pension funds, Burk has little to say about the rest of the control ap- 
paratus over stocks and corporations, such as the Securities Exchange Commission. A larger view must take into account the interplay of public regulation with private.

Accountants sometimes treat separately the application of accounting standards for balance sheet and income reporting from tax related reporting. Implicit is an underlying assumption that the balance sheet is a tool of rationality, as opposed to the opportunities of tax reporting. Obviously, the distinction is less important to a fully behavioral, socially nested view of accounting. Yet it is clear that changes in tax law shape the choice of accounting rules. Tax law shapes management decisions, and accounting rules are chosen partly in terms of their tax implications in the short and medium run. In this sense tax law, if not a control agent, operates in the same manner as a norm enunciated by the Financial Accounting Standards Board in shaping both accounting rule choice and behavior. So, any examination of the rule setting-surveillance apparatus ought to focus on tax law related standards as well as professionally mandated standards. A significant agenda item for the future involves the interplay of control mechanisms and institutions.

\section{ENTERPRISE FORM, INDUSTRY AND ACCOUNTING}

Every accountant knows that the type of accounting used is dictated by enterprise form. Not-for-profits and governmental agencies tend to use forms of fund accounting, profit making firms use double-entry accounting and income statement reconciliation. Not-for-profit and governmental agencies typically do not institute depreciation reserves, nor do they include separate capital accounts. Accounting form is partly related to the structure of control and funding, but it is also related to institutionalized rule systems. After all, American state legislators could require universities to charge students for depreciation of dorms and of university buildings. That is, there is nothing inherent in the form of accounting systems that we use any specific rule.
There is a logic to their adoption, but there are alternate logics which grow out of the institutionalized rationality of political economic systems.

There is a received wisdom about the consequences of accounting and budgeting forms for economizing, for decision-making about the use of money. It is believed, for instance, that not-for-profits over-invest in fixed assets because they are not required to fund depreciation accounts, nor do they worry in the short run about operating expenditures attached to bricks and mortar. Similarly, goverumental bureaucrats are believed to have little incentive to economize and have a positive incentive to expand annual budgets. From the point of view of the sociology of organizations it would be useful to have the received wisdom and related specu. lation synthesized. From Niskanen (1971), and others, we could begin to develop a sense of the recurrent pitfalls of budget forms, investment rules and incentive systems. Fama \& Jensen's (1983) extension of property-rights, agency theory to show how residual claimants are treated under different enterprise forms, lays out a scaffolding for analysis. But even within enterprise form, industry differences lead to the development of industry specific rules and regimes. In this section I want to ask how industrial differences relate to capital markets and accounting rules.

Most of the sociology of organizations has tried to focus on organization as a general phenomenon. Often organizational theorists have really had in mind organizations with monetary reimbursement for labor. Thus governments and businesses could be studied as one general form, ignoring voluntary associations, churches and social movement organizations. In recent years, an interest in technology, task structure variables and environments, has led some writers on organizations to realize that organizational variability is strongly linked to underlying industry variability, that organizations with similar products and production systems might have similar life cycles, internal structures, career patterns and inter-organizational relations (Hirsch, forthcoming; Dess \& 
Beard, 1984). We have just begun to exploit industry as an object of analysis. For many purposes, it may be more important than what I have called "enterprise form". Compare profit making and not-for-profit hospitals. Surely, they are different in their economizing incentives, but they are similar in their complexity, extent of government regulations, problems of authority, labor markets, and rates of technological change.

One aspect of industry is the accounting-taxation regime that applies to it. This is well-tread ground for the accountant. Problems of depreciation, the establishment of reserves for risktaking, are well understood. There are specialists in the treatment of research and development expenses, in gas and oil exploration accounting and capitalization, in insurance accounting. As new products are created with different technologies, visibility of results and time horizons, risk and monopoly characteristics, accountants, legislatures and lawyers confront the problems of assessing value and developing mechanisms of accounting. As this. happens, each industry, or many industries, develop a relatively distinct accounting taxation regime.

Soon, I believe, we will have a map of organization-industry characteristics that tells us much about specific organizations based upon the industry in which they exist (Dess \& Beard, 1984). We will be able to say something about the socio-demographics of labor, size, rates of growth, concentration ratios, turnover and unionization, all as a function of industry. We also will know how particular industries interface with other industries. What we need as an accompaniment is a parallel map of the accounting, budgeting capital regimes.

It is my belief that the enterprise form chosen in an industry is partly a response to problems of accounting and income reporting in particular. The structure of investment in gas and oil exploration and in construction is partly a function of the rule system and incentives that are in operation in these particular industries under capitalism. (They do it differently in the Soviet Union!) Whether an industry is populated by partnerships, privately held corporations, pub- licly owned corporations or proprietorships, relates to capital demands and flows, which are shaped by accounting devices, tax law and in. vestment instruments.

In construction, the largest companies have net worths that would easily rank them in the Fortune 500 . Yet they tend to be family-held, private corporations; they are heavily dependent upon capital gains and the intricacies of depreciation rules for their profitability. Return on investment may be high in the long term, but annual profits from operating income may be quite low in the short term. Indeed, net worth may grow based on unrealized capital gains, while annual profits may be negative. There are other reasons that large property firms are not publicly held. Capital is easily raised through mortgages for tangible assets, for instance, so that stock ownership as a mechanism for raising capital is not required. A similar kind of analysis explains the capital flow and structure of the two-tiered oil and gas exploration industry. One tier, the majors, internalizes risks across many different exploration sites or in consortiums of majors. A second tier uses the advantages of tax codes and quick write-offs to create limited partnerships for exploration. In doing so, a tier of an industry ties into the income tax laws related to individuals.

To a great extent, I believe that the inter-connections of industry and capitalist class fragments can be better understood if we treat them - not just as related to product-technology classes alone, but if we treat them in relationship to investment tax opportunity created by the complex accounting/tax laws which govern specific industries.

\section{INTERNAL AND EXTERNAL BUDGETING AND ACCOUNTING PROCESSES}

Here, I discuss internal and external budgeting systems and rules and the problem of developing sociological theory about them. By $e x$. ternal budgeting systems and rules I mean any long-term formula for revenue transfer. Spot contracts are related to pure markets, but all 
government reimbursement formula or long term contractual relations create long-term budget-revenue systems. A reimbursement or funding rule creates a dependency relation when a significant portion of revenue comes from one source over an extended time period. Thus, the contract-accounting rules between suppliers and manufacturers, as well as between manufacturers and dealers in the automobile industry, can be subjected to systematic analysis. Similarly, the reimbursement formulas and related systems for hospitals, schools and universities can be subjected to systematic analysis. External budgeting, funding rules and procedures can have a range of impacts on the operation of the organizations to which they apply.

First, and a most traditional topic for organizational analysis, they affect organizational structure in a very basic sense. The billing-reimbursement system creates a demand for clerical. billing activity. The more detailed the reporting requirements and the greater the number of reimbursing agents with different requirements, the more organizational personnel are involved in the funding system. It has been estimated that the difference in reimbursement systems for hospital care in Canada and the United States account for as much as $12 \%$ of the differential costs of hospitals in those countries. To the extent that each medical test, supplies and procedures for each individual must be accounted for in order to receive reimbursement from either a patient or an insurance company, as contrasted with either total budget reimbursement or with diagnostic category reimbursement, one can easily see the differential in reporting requirements.

Second, external funding formulas shape organizational choices and policies. In the medical system the reimbursement formula affects patient care decisions - not only who to treat, but how to treat. Choices of specific processes, choices of in-hospital treatment versus external treatment are all subject to reimbursement formula issues. In high schools, attendance policies are set partly in response to "student days" components of state reimbursement formulas.

Third, in some cases, reimbursement formulas and agreements relate to the shape of organiza- tional goals and major product strategies. Public universities have to choose between an in-state and out-state clientele, partly dependent upon state regulation of the proportion of out-state students and tuition differentials. Medical schools reduce or expand their entering classes and choose mixes of research and training partly in response to similar kinds of constraints.

Finally, the formulas and reimbursements are related to other control systems. How much quality oversight accompanies the reimbursement relationship? How directly and deeply are funders able to intervene in setting organizational goals and priorities? Being a supplier to IBM involves you not only in a deep technical relationship in which IBM personnel nurse and supervise your work, but also involves you in a level of secrecy only matched by working on new weapons systems.

Let me now turn to a discussion of internal budgeting and accounting systems. It is here that most progress has already been made. The longterm transformation of organizations in Western society has been accompanied by real innovations in internal budgeting and accounting. Chandler (1977) has discussed the growth of cost-accounting as a necessary tool of rationality for upper management facing 2 diverse and complex company. The development of the notion of profit centers within enterprises that located both expenditures and income at a sub-enterprise level, was a major transformation of organization that leads to a change in the locus of authority and the incentive expectation system surrounding managerial roles. Profit centers and divisional decentralization can be seen as the major social invention allowing organizations to overcome the problem of diseconomies of scale (Chandler, 1962).

Other organizations besides corporations have variations of profit center accounting and budgeting. Hospitals treat clinics and departments as profit centers and universities, such as Harvard and Vanderbilt, have a "bottoms-up" approach (or "each tub on its own bottom"), in which as many costs as possible are allocated to units and in which tuition, research and endowment funds are debited to schools. To the extent 
that profit center logic is a major determinant of allocations and priority setting for units, an economizing logic is imposed within the enterprise: an economizing logic of internal capitalism, in fact.

Indeed, profit center logic implies a level of intra-enterprise competition and intra-unit competition much like that of the market. Profit center systems immediately raise the issue of transfer pricing and the politics of transfer pricing within organizations. It should be noted that how one determines transfer prices and decisions runs into both political and culturalsymbolic problems and choices. Upper-level authorities have to have adjudicatory rules and mechanisms for resolving conflicts stemming from the price setting and purchasing decisions internal to the firm. The cultural-symbolic problem stems from the criteria for costing and pricing. The rationality of economics is different from the rationality-practice of accounting in evaluating marginal costs and arriving at pricing decisions (Abdel-Khalik \& Lusk, 1974; Swieringa \& Waterhouse, 1982). Recently Eccles (1984) has shown that transfer pricing systems vary systematically between corporations with different degrees of vertical integration.

Another aspect of accounting and information systems within organizations is the development of alternative indices of unit performances. Deans at prestigious universities count the number of Guggenheims received, the amount of grant money, and the number of memberships in the National Academy of Sciences, as well as the number of student enrolments. Pharmaceutical companies develop refined measures of quality. In the more refined systems we move away from accounting per se to the borderlines of operation research and statistical theory. Some of the same questions asked about external funding apply here. How does the system shape organizational structure? How does the accounting system affect substantive decision making? Does it, for example, lead one school in the University to try and raid another school for students, depending upon the tuition transfer price that is allocated? Does the accounting rule and the budget system affect the locus of discretion and decision making? It should be pointed out that the literature on alternative governmental budgeting systems quite directly asks "how does a change in budgeting systems affect who gets to decide what," as much as it does the question of "does the difference in the system change substantive decisions?" What games and coalitions possibilities are created by different accounting rules and budget systems within the organizations? (Wamsley, 1983).

A final aspect of budget and rule systems in organizations has to do with the sociology of capital and investment decisions. It is striking how few systematic studies we have of how major decisions of capital allocation are made in organizations. Textbooks treat the growth of return on investment thinking in the $1950 \mathrm{~s}$ as a systematic tool for analyzing investment decisions, yet we have little discussion of how major investment decisions are made in a variety of organizations, little comparative study of the efficacy of formal procedures and rationality. Aside from Louis Pondy's early study (1964) it is hard to come across a systematic analysis of both the structure of investment decision-making and the game as it gets played out in that process (cf. Pettigrew, 1973).

The internal rules and budget systems encompass the life of the manager. Although overall budget regimes evolve and accounting rules change, the operating manager acts as a rule taker. The individual decisions of managers and the cumulative force of those decisions on the directions of organizational.change are partly shaped by budget formulas and accounting rules.

\section{CONCLUSIONS}

I have sketched an approach to accounting rules, budget systems and enterprise forms and rules that would permit organizational theory to become less abstract, to be more in tune with the historically evolving normatively guided system that surrounds organizations and the managers within them. The sociological theory of organizations, I have argued, assumes an account- 
ing-budgeting regime. But those regimes can be treated as sociologically problematic. Both in the long run, in the adoption of such systems as double entry book-keeping, and in the short run in changing depreciation rules, organizational behavior, choice and directions are shaped by the rule or system adopted. This is not news to accountants. It is news to sociologists.

It should be clear that what is proposed will have radical consequences for the way sociologists do their business. I have argued that understanding the budget-accounting regime requires attention to the historical-external processes surrounding industries within the changing socio-economic system. Enterprise form and industrial differences will enter as key topics in the sociology of organizations.

Although what is proposed may not be news to accountants, it will have consequences for them as well. For too long accounting and budget processes have been separated from the corpus of social science analysis. A two-way street may be opened.

\section{BIBLIOGRAPHY}

Abdel-khalik, A. R. \& Lusk, E. J., Transfer-Pricing - a Synthesis, The Accounting Review (January 1974) pp. 8-23.

Braverman, H., Labor and Monopoly Capital: The Degradation of Work in the Twentieth Century (New York: Monthly Review Press, 1974).

Burawoy, M., The Manufacturing of Consent (Chicago, University of Chicago Press, 1979).

Burawoy, M.. Between the Labor Process and the State: The Changing Face of Factory Regimes Under Advanced Capitalism, American Sociological Review (October 1983) pp. 587-605.

Burk, J., The American Stock Market: A Sociological Essay of its Institutional Development, 1900-1975, unpublished PhD dissertation, Department of Sociology, University of Chicago, 1982.

Chandler, A. D. Jr., Strategy and Structure: Chapters in the History of the Industrial Enterprise (Cambridge, MA: MIT Press, 1962).

Chandler, A. D. Jr., The Visible Hand: The Managerial Rewolution in American Business (Cambridge, MA: Harvard University Press, 1977).

Clark, B., The Higher Education System: Academic Organizations in Critical Perspectives (Berkeley: University of California Press, 1983).

Clawson, D.. Bureaucracy and the Labor Process: The Transformation of U.S. Industry, 1860-1920 (New York: Monthly Review Press, 1980 ).

Clegg, S., Organization and Control, Administrative Science Quarterly (December 1981) pp. 545-62.

Crozier, M. \& Friedberg, E., Actors and Systems: The Polttics of Collective Action (Chicago: University of Chicago Press, 1980).

Davis, J. P., (Corporations (New York: Capricorn, 1961 ).

Dess. G. G. \& Beard, D. W., Dimensions of Organizational Task Environments, Administrative Science Quarterly (March 1984) pp. 52-73.

Eccles, R. G.. The Transfer Pricing Problem: A Theory for Practice, unpublished manuscript, Harvard School of Business, Cambridge MA: 1984).

Edwards, R., Contested Terrain (New York: Basic Books, 1979).

Fama, E. F. \& Jensen. M. C., Separation of Ownership and Control, Journal of Law \& Economics (June 1983 ) ppo. 301-325.

Feldman M. \& March, J. G. Information in Organizations as Signal and Symbol, Administrative Science Quarterly (June 1981) pp. 171-86.

Goidman. P., Mainstream and Critical Perspectives on Organizations: Shared and Conflicting Domains, unpublished paper, Department of Sociology, University of Oregon, Eugene, OR, 1984).

Gouldner, A.. Patterns of Industrial Bureaucracy (Glencoe, IL: Free Press, 1954).

Hall, R. Organizations: Structure and Process (Englewood Cliffs, NJ: Prentice-Hall, 1982).

Hannan, M. \& Freeman, J., The Population Ecology of Organizations, American Joumal of Sociology (January 1977) pp. 929-40.

Hirsch, P., The Study of Industries, in Bachrach, S. (ed.) Researcb in the Sociology of Organizations Vol. 5 (Greenwich. CT: JAI Press, forthcoming). 
Holthausen, R. W. \& Leftwich, R. W., The Economic Consequences of Accounting Choice: Implications of Costly Contracting and Monitoring, Journal of Accounting and Economics (March 1983) pp. 77-117.

McNeil, K, Understanding Organizational Power: Building on the Weberian Legacy, Administrative Science Quarterly (March 1978) pp. 65-90.

Meyer, J. W. \& Rowan, B., Institutionalized Organizations: Formal Structure as Myth and Ceremony, American Jourmal of Soctology (September 1977) pp. 340-63.

Mintz, B. \& Schwartz, M., Tbe Power Structure of American Business (Chicago: University of Chicago Press, 1985).

Niskanen, W. A., Bureaucracy and Representative Government (Chicago: Aldine, 1971).

Perrow, C., Authority, Goals and Prestige in a General Hospital, unpublished doctoral dissertation, University of California, Berkeley, 1960.

Perrow, C., Complex Organizations A Critical Essay, 2nd edn (Glenview, IL: 1979).

Pettigrew, A. M., Tbe Politics of Organizattonal Decision-Making (London: Tavistock, 1973).

Pfeffer, J., Organtzations and Organtzation Theory (Marshfield, MA: Pitman, 1982).

Pondy, L, Budgeting and Inter-group Conflict in Organizations, Pittsburgb Business Review (January 1964) pp. 1-3.

Scott, W. R., Organizations: Rational, Natumal and Open Systems (Englewood Cliffs, NJ: Prentice-Hall, 1981 ).

Selznick, P., Foundations of the Theory of Organizations, American Sociological Review (February 1948) pp. 25-35.

Selznick, P., TVA and the Grass Roots (Berkeley: University of California Press, 1949).

Skowronek, S., Building A New American State: Tbe Expansion of National Administrative Capacity (New York: Cambridge University Press, 1982).

Stinchcombe, A. W., Third Party Buying: The Trend and the Consequences, Soctal Forces (June 1984) pp. 861-884.

Swieringa, R. J. \& Waterhouse, J. H., Organizational Views of Transfer Pricing, Accounting Organizations and Society (1982) pp. 149-165.

Therborn, G., What Does the Ruling Classing Do Wben It Rules? State Apparatuses and State Pouver Under Feudalism, Capitalism and Socialism (London: NLB, 1978).

Thompson, J. D., Organizations in Action (New York: McGraw Hill, 1967).

Wamsley, G., Budgeting: Strategic Instrument or Mindless Ritual, in Eddy, W. B. (ed.) Handbook of Organization Management pp. 327-64 (New York: Marcel Dekker, 1983).

Watts, R. L \& Zimmerman, J., Toward a Positive Theory of the Determination of Accounting Standards, The Accounting Review (January 1978) pp. 112-34.

Wildavsky, A, The Politics of the Budgetary Process 3rd edn (Boston: Little Brown, 1979).

Wiley, M. G. \& Zald, M. N., The Growth and Transformation of Educational Accrediting Agencies: An Exploratory Study on Social Control of Institutions, Sociology of Education (Winter 1968) Pp. 36-56.

Zald, M. N., Organizational Cbange: The Poltical Economy of the MMCA (Chicago: University of Chicago Press, 1970a).

Zald, M. N., The Political Economy of Organizations: A Comparative Framework, in M. N. Zald (ed.) Power in Organizations pp. $221-61$ (Nashville, TN: Vanderbilt University Press, 1970b).

Zald, M. N., On the Social Control of Industries, Social Forces (September 1978) pp. 79-102.

Zald, M. N. \& Hair, F. D., The Social Control of Hospitals, in Georgopoulos, B. (ed.) Organization Researcb on Healtb Institutions pp. 51-82 (Ann Arbor, MI: Institute of Social Research, 1972).

Zimbalist, A., (ed.), Case Studies on the Labour Process (New York: Monthly Review Press, 1980). 